\title{
The Fiscal Effects of Foreign Aid in Lesotho
}

\section{Retselisitsoe Isaiah Thamae}

Department of Economics, National University of Lesotho, Email: rthamae@gmail.com

\section{Lineo Gloria Kolobe}

Department of Economics, National University of Lesotho

\section{Doi:10.5901/mjss.2016.v7n1p116}

\begin{abstract}
Lesotho has historically depended on foreign aid. This paper seeks to understand the fiscal effects of such aid inflows on Lesotho's economy over the period 1982-2010. The cointegration test results indicate a strong negative long-run association between recurrent expenditure and foreign aid, and a positive but marginally significant relationship between aid and capital expenditure. These findings provide lack of evidence for the presence of aid fungibility since foreign aid is not diverted to nondevelopment expenditure. The Lesotho Highlands Water Project also seems to have been effective in terms of changing government budgetary allocations and has had a positive impact on development spending. This supports the notion that provision of loans instead of grants results in an effective use of government funds.
\end{abstract}

Keywords: Foreign Aid; Fungibility; Fiscal Policy; Cointegration; Lesotho.

\section{Introduction}

Lesotho has historically depended on foreign aid. From 1960 to 2010 (see figure 1 in section 2), the country has experienced substantial fluctuations in foreign aid flows, with an upward trend till the mid-1980s and a downward trend thereafter. Between 1960 and 1969, foreign aid as a share of gross domestic product (GDP) was approximately 16\%, rising to $26 \%$ between 1980 and 1989 and sharply falling to $8 \%$ in the last period (2000-2010). The fluctuation raises many issues such as: How have governments responded to these fluctuations in foreign aid? Did foreign aid influence government spending and its revenue collection efforts? Lastly, does provision of loans instead of aid grants results in the effective use of government funds in Lesotho?

In order to address some of these issues, Devarajan et al. (2006) analysed the extent of aid fungibility in subSaharan Africa, including Lesotho. They discovered that aid is partially fungible in those countries, with foreign aid resulting in an equal increase in both recurrent and capital spending. However, that study suffers from problems related to panel data analysis such as the influence of outliers and the heterodoxity of sample countries. Other studies have addressed the fiscal effects of aid at country-specific level (see Bhattarai, 2007; Fagernas and Roberts, 2004a, 2004b; Fagernas and Schurich, 2004; Swaroop et al., 2000; Pack and Pack, 1990), but none of these covered Lesotho as one of the aid-recipient economies. Thus, given that the effect of foreign aid on economic growth depends ultimately on how the government responds to aid flows (see Bhattarai, 2007), the paper aims at investigating the effects of aid inflows on government spending and revenue patterns as well as budgetary allocations in Lesotho during the period 1982-2010. The study uses multivariate cointegration techniques in order to account for the possibility of spurious regression among time trend variables and simultaneity between foreign aid and economic growth. It also adds to the literature of the effects of foreign aid in emerging economies by providing the experience of Lesotho as an aid-dependent country.

The remainder of the paper is organised as follows. Section 2 provides a background to Lesotho's economy and an overview of the country's aid inflows. Section 3 reviews the literature on fiscal effects of foreign aid while section 4 outlines the methodology. The results are discussed in section 5 . Concluding comments and recommendations are presented in section 6 .

\section{Economic Background and Aid Inflows}

Lesotho is a small open economy in southern Africa with a per capita income of US $\$ 1000$ and growing at rate of about $4 \%$ over the past ten years (see Thamae, 2013). The growth was driven mainly by textile manufacturing sector, owing to 
the African Growth and Opportunity Act (AGOA) of the United States, and major investments in the diamond mining industry. In addition, Lesotho's economic progress depends on the developments in South Africa (SA) through the royalties earned from water resources transferred to SA, under the Lesotho Highlands Water Project (LHWP), and the remittances from mine-workers hired in SA. According to IMF (2012), Lesotho also imports about 80\% of its good and services from SA while SA buys 25\% of Lesotho's exports. Furthermore, Lesotho and SA are members of the Common Monetary Area (CMA), the Southern African Customs Union (SACU) and the Southern African Development Community (SADC) (see Thamae, 2012). In the case of the SACU membership, Lesotho continues to benefit in terms of revenue transfers that account for about $50 \%$ of the country's public revenue, making it a significant share of public spending (see Masenyetse and Motelle, 2012).

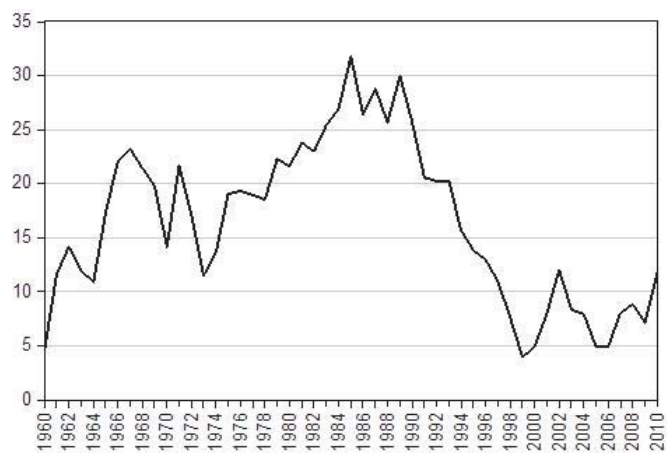

Figure 1. Foreign aid as a share of GDP (in percent), 1960-2010

Source: Own computations.

The country has also historically depended on foreign aid. As shown in figure 1, aid inflows as a percentage of GDP have increased on average from approximately 16\% to 26\% between 1960 and 1989. In line with Matlosa (1999), this was the period of early evolution of Lesotho's aid industry, an industry based on the international sympathy for the country being held hostage around 1976 by the then isolated SA regime. This sympathy helped the country to mobilise aid from donor nations in a way that has never happened before. However, the military coup of 1986-1993 that replaced the civilian government did not meet the standard aid conditionalities of economic liberalisation and political pluralism and had adverse implications for the inflows of foreign aid to the country. Consequently, aid fell sharply from $26 \%$ to about $15 \%$ between 1980 and 1999. The political instabilities of 1994 and 1998 also made some donors to withhold aid and close their offices within the country. This contributed to a further decline in foreign aid flows, which have remained at about $8 \%$ in the last decade of 2000-2010.

\section{Literature Review}

One of the main objectives of foreign aid is to promote economic growth and reduce poverty in majority of developing economies. This view is based on the idea that foreign aid can boost investment by reducing savings gap at early stages of economic development as well as foreign exchange gap at later stages (Chenery and Strout, 1966). Given that capital markets in most developing countries are underdeveloped, foreign aid can therefore finance profitable development projects that may not be undertaken as a result of lack of domestic savings or foreign exchange required for capital goods imports. Furthermore, foreign aid can lead to faster economic growth and higher investment through fiscal policy by reducing distortionary taxes used to finance productive public expenditures (Boone, 1996; Barro, 1990). However, inflows of foreign aid may encourage governments in developing countries to be slack in their tax revenue collection effort and pursue policies that favour larger budget deficits. This in turn can result in larger savings-investment gaps, which require more flows of foreign aid (Bhattarai, 2007).

Swaroop et al. (2000) further argued that sometimes the preferences of aid-recipient countries differ from those of the donor agencies. This results in aid being substituted for domestic resources - the concept of fungibility, and relaxes the budget constraint of the recipient government. According to Chatterjee et al. (2012), this behavioural aspect of aiddependent economies, which arises when the monitoring process is too costly for the donor, may offset the intended 
positive effects of aid in influencing economic growth and other macroeconomic outcomes. The phenomenon of aid fungibility implies that the final impact of foreign aid on economic growth depends on the response of the recipient government towards foreign aid inflows. This called for the need to understand the fiscal effects of aid in developing countries.

Although foreign aid is generally given to finance capital expenditures, studies from some developing countries provide evidence to suggest the presence of aid fungibility. These studies also tested the hypothesis that aid encourages recipient governments to be slack in their tax revenue collection and pursue macroeconomic policies that are in favour of higher budget deficits. For example, using the Johansen cointegration technique, Bhattarai (2007) revealed that the longterm association between foreign aid and recurrent spending in Nepal is stronger than that between foreign aid and capital spending, a finding that supports the idea of aid fungibility. However, the study found no evidence supporting the hypothesis that the government becomes slack in tax revenue collection as a result of the availability of aid.

Furthermore, results from a panel study by Chatterjee et al. (2012) provided strong evidence of aid fungibility at aggregate level within a sample of countries including developing economies, with the investment aid being the most fungible. The study also indicated that in the presence of aid fungibility, there is very little association between aid and economic growth, implying the diversion of aid to non-development expenditure retards economic growth. Devarajan et al. (2006) in a cross-country analysis of sub-Saharan Africa discovered that aid is partially fungible, with foreign aid resulting in an equal increase in both recurrent and capital spending. Nonetheless, the study argued that the reallocation of aid to recurrent expenditure may not necessarily be harmful since aid helps some of those countries to meet their debtservicing payments and to spend in other important sectors such as education.

In contrast, Pack and Pack (1990) found that foreign aid in Indonesia did not displace development expenditures but it actually stimulated total government spending. This suggests that foreign aid in Indonesia was spent on purposes for which it was intended by the donor nations. Similarly, findings from the single-country studies by Fagernas and Schurich (2004) as well as Fagernas and Roberts (2004a, 2004b) in Malawi, Uganda and Zambia, respectively, indicated that a rise in foreign aid induces an increase in development budget expenditure, suggesting that aid did not discourage tax collection efforts or reduce domestic borrowing.

\section{Methodology}

\subsection{Model}

The study adopts a variant of aid fungibility model from Swaroop et al. (2000) for a developing economy that spends on two types of public goods - non-developmental or recurrent $\left(G_{1}\right)$ at price $p_{1}$ and developmental or capital $\left(G_{2}\right)$ at price $p_{2}$. Given that the government has an amount $A$ of foreign aid assigned for developmental purposes, it can make aid fungible by taking a certain portion $\alpha(0 \leq \alpha \leq 1)$ of it as its revenue while using the remainder for developmental purposes. Assuming that $p_{1}, p_{2}$ and $\alpha$ are given and considering that the government finances its total expenditures through domestic revenue, $R$, plus the portion of fungible aid, its budget constraint can be specified as follows:

$p_{1} G_{1}+p_{2} G_{2}=R+\alpha A$

The left-hand side of equation (1) shows the total government expenditure while the right-hand side gives its fungible funds since only the non-fungible portion of foreign aid, $(1-\alpha) A$, is used to purchase $G_{2}$ and cannot be used to augment government's discretionary resources. given by

The government then chooses $G_{1}$ and $G_{2}$, which maximise the social welfare, subject to the budget constraint

$$
\begin{aligned}
& W=W\left(U^{1}, U^{2}, \ldots, U^{n}\right) \\
& \text { where } \\
& U^{n}=U^{n}\left(C_{p}^{n}, G_{1}, G_{2}\right)
\end{aligned}
$$

Equation (3) shows that the utility of the representative citizen, $U^{n}$, depends on individual private consumption, $C_{p}^{n}$, and the two public goods provided by the government. In making resource allocation choices, aid is assumed to have no impact on $R$ and is taken as given although this assumption is relaxed later.

The maximisation of the social welfare function given by equation (2) subject to the budget constraints in equation (1) results in the following first-order condition:

$U_{G_{1}}^{n} / U_{G_{2}}^{n}=p_{1} / p_{2}$

This condition implies that to maximise welfare, $G_{1}$ and $G_{2}$ are chosen in such a way that the marginal rate of substitution of the two public goods is equal to the price ratios. However, given that majority of developing economies have data in aggregate form rather than on separate prices and quantities, the transformation of the demand equations 
from the model of fungibility into expenditure equations is necessary.

The use of the Stone-Geary utility function in equation (3), which is maximised subject to the budget constraint in equation (1), yields the following linear expenditure functions in a form of regression models with identifiable parameters for both recurrent and capital expenditures, respectively (see Bhattarai, 2007; Pack and Pack, 1990, 1993):

$$
\begin{aligned}
& G_{1, t}=\beta_{10}+\beta_{11} Y_{t}+\beta_{12} A_{t}+\beta_{13} L H W P+\varepsilon_{1, t} \\
& G_{2, t}=\beta_{20}+\beta_{21} Y_{t}+\beta_{22} A_{t}+\beta_{23} L H W P+\varepsilon_{2, t}
\end{aligned}
$$

where $Y$ is the national income (or GDP), $\varepsilon$ is the white noise error term, $\beta$ 's are parameters to be estimated. The dummy variable, $L H W P$, which is equal to 1 for the period from 1986 onwards and 0 otherwise, captures the impact of the Lesotho Highlands Water Project on the budgetary allocations of the government. This variable is included to determine whether the provision of loans instead of grants results in the effective use of government funds (see Djankov et al., 2006). Considering equation (5), a positive and significant coefficient on foreign aid will indicate a diversion of foreign aid to recurrent spending. This will therefore be consistent with the idea that aid is fungible.

Domestic revenue was assumed to be fixed when determining the effects of foreign aid on the choice between recurrent and capital spending. In order to allow for the possibility revenue effects of foreign aid, domestic government revenue, $R_{t}$, is modelled as a linear function of economic growth and aid (including the $L H W P$ dummy) as follows:

$$
R_{t}=\beta_{30}+\beta_{31} Y_{t}+\beta_{32} A_{t}+\beta_{33} L H W P+\varepsilon_{3, t}
$$

Given the available data, equation (7) can therefore be estimated along with the linear expenditure functions in equations (5) and (6) to analyse the fiscal effects of aid in Lesotho.

\subsection{Estimation Strategy}

The augmented Dickey-Fuller (ADF) unit root test is first used to determine the order of integration of the series (Dickey and Fuller, 1979, 1981). If the series are all integrated of order one, the Johansen's $(1988,1995)$ multivariate cointegration procedure is adopted to estimate equations (5) to (7). In order to establish whether there is cointegration among variables, the estimation of the unrestricted vector autoregression (VAR) model through the maximum likelihood method is conducted, with the choice of the appropriate lag length being based on the information criterion. The trace and the maximum eigenvalue statistics are then used to determine the cointegration rank. If there is cointegration, the estimation of the error correction model $(E C M)$ is undertaken to analyse the short-run and long-run dynamics of the variables. Finally, the study will investigate the Granger causality within the ECM multivariate formulation (Engle and Granger, 1987).

\section{Data and Results}

\subsection{Data}

The study uses time-series data covering the period 1982-2010. ${ }^{1}$ Table 2 then gives summary statistics of the variables used in this study. The data on government revenue and expenditure as well as GDP are sourced from the International Monetary Fund (IMF) World Economic Outlook Database (October, 2012) and the Ministry Finance, with all real variables being in 2004 prices. Foreign aid data is obtained from the World Bank Development Indicators (2012).

Table 2. Summary statistics

\begin{tabular}{lcccc}
\hline Variable & Mean & Standard Deviation & Minimum & Maximum \\
\hline GDP, $Y$ & 3,625 & 188 & 2,557 & 5,396 \\
Foreign Aid (percentage of GDP), $A$ & 15.75 & 8.97 & 3.96 & 31.80 \\
Revenue, $R$ & 1,799 & 755 & 801 & 3,450 \\
Recurrent Expenditure, $G_{1}$ & 1320 & 257 & 982 & 1,827 \\
Capital Expenditure, $G_{2}$ & 575 & 391 & 68 & 1,301 \\
\hline
\end{tabular}

Note(s): All the series, except foreign aid, are in per capita form.

\footnotetext{
1 There no data on government capital expenditure prior to 1982.
} 


\subsection{Unit Root Tests}

The ADF test is used to establish the presence of unit root among the series and the optimal lag length is determined by the Schwarz information criterion (SIC). The results reported in table 3 indicate that all the series have unit root, with test statistics for first differenced variables being significant at the $1 \%$ level. This could imply that there is a stable and longterm relationship among the series.

Table 3. ADF tests

\begin{tabular}{|c|c|c|c|c|}
\hline \multirow[t]{2}{*}{ Variable } & \multicolumn{2}{|c|}{$\boldsymbol{H}_{0}$ : non-stationary in levels } & \multicolumn{2}{|c|}{$H_{0}:$ non-stationary in first differences } \\
\hline & Test statistic & $p$-value & Test statistic & $\mathrm{p}$-value \\
\hline $\bar{Y}$ & 1.016 & 0.996 & -7.124 & 0.000 \\
\hline$A$ & 1.783 & 0.999 & -7.560 & 0.000 \\
\hline$R$ & -2.275 & 0.186 & -6.281 & 0.000 \\
\hline$G_{1}$ & -0.507 & 0.876 & -4.006 & 0.005 \\
\hline$G_{2}$ & -2.612 & 0.102 & -4.612 & 0.001 \\
\hline
\end{tabular}

Note(s): All the series are in log form.

\subsection{Cointegration Tests}

The Johansen multivariate cointegration method is applied to ascertain the presence of long-run association among the series. The appropriate lag length chosen by SIC is 1 for all the VAR models. The cointegration test results for equation (5) relating recurrent expenditure to foreign aid and GDP are presented in table 4. The maximum eigenvalue test results reported in part $A$ of the table show that there is cointegration at the $5 \%$ level of significance. The estimation results of the normalised cointegrating equation are reported in part B reveal that non-development expenditure is positively related to GDP, but has a negative and significant association with foreign aid. These findings provide no evidence for the presence of aid fungibility since no diversion of aid to recurrent expenditure is found (see similar findings by Pack and Pack, 1990). The Lesotho Highlands Water Project, however, seems to have been effective in terms of changing government budgetary allocations since the coefficient of LHWP dummy is negative and significant. This finding supports the idea that provision of loans instead of grants results in the effective use of government funds (see Djankov et al., 2006).

Table 4. Cointegration test results for recurrent expenditure model

\begin{tabular}{ccccc}
\hline \multicolumn{5}{c}{ Part A: Maximum eigenvalue test } \\
\hline Maximum rank & Eigenvalue & Max-eigen statistic & 0.05 critical value \\
\hline 0 & 0.608 & 25.31 & 22.30 \\
1 & 0.170 & 5.032 & 15.89 \\
2 & 0.093 & 2.638 & 9.165 \\
\hline$G_{1}$ & Part B: Normalised long-run equation & Constant \\
\hline 1.000 & $Y$ & $A$ & LHWP & -1.927 \\
& -0.703 & 0.132 & 0.063 & $(-1.679)$ \\
\hline
\end{tabular}

Note(s): t-statistics are in parentheses; $L W H P$ dummy is shown in part B for convenience and the sign of its coefficient and $\mathrm{t}$-statistic is considered positive, but it is actually negative (from the ECM).

The cointegration test results for equation (6) relating capital expenditure to foreign aid and GDP are reported in table 5. The trace test, reported in part A shows that there is one cointegrating vector at the $5 \%$ significance level and its normalised estimated coefficients are reported in part B. The results in part B indicate a strong positive long-run association between capital expenditure and GDP, while there is a positive but marginally significant association between foreign aid and capital spending. A positive and significant coefficient of the LHWP dummy is also found, implying that the Lesotho Highlands Water Project has had a positive impact on capital spending by the government. 
Table 5. Cointegration test results for capital expenditure model

\begin{tabular}{cccc}
\hline \multicolumn{4}{c}{ Part A: Trace test } \\
\hline Maximum rank & Eigenvalue & Trace statistic & 0.05 critical value \\
\hline 0 & 0.481 & 28.51 & 24.28 \\
1 & 0.318 & 10.82 & 12.32 \\
2 & 0.018 & 0.489 & 4.130 \\
\hline \multicolumn{4}{c}{ Part B: Normalised long-run equation } \\
\hline$G_{2}$ & $Y$ & $A$ & LHWP \\
\hline 1.000 & -0.515 & -0.385 & -0.406 \\
& $(-3.324)$ & $(-1.164)$ & $(-3.548)$
\end{tabular}

Note(s): t-statistics are in parentheses; LWHP dummy is shown in part B for convenience and the sign of its coefficient and $t$-statistic is considered negative, but it is actually positive (from the ECM).

Table 6 presents the results of cointegration for equation (7), which captures the relationship between government revenue, GDP and foreign aid. The maximum eigenvalue test shows that there is no cointegration between the three variables. This result contradicts the view that the availability of foreign aid makes the government to become lax in mobilising domestic revenue. n. These findings are similar to those reported by Fagernas and Schurich (2004) as well as Fagernas and Roberts (2004a, 2004b), which show that the presence of foreign aid in Uganda, Zambia and Malawi does not discourage tax collection efforts by the governments of these countries.

Table 6. Cointegration test results for revenue model

\begin{tabular}{cccc}
\hline \multicolumn{4}{c}{ Maximum eigenvalue test } \\
\hline Maximum rank & Eigenvalue & Max-eigen statistic & 0.05 critical value \\
\hline 0 & 0.201 & 6.057 & 17.80 \\
1 & 0.150 & 4.395 & 11.22 \\
2 & 0.108 & 3.090 & 4.130 \\
\hline
\end{tabular}

Note(s): t-statistics are in parentheses.

\subsection{Granger Causality Estimation Results}

The results of Granger causality, investigated within the ECM multivariate formulation are presented in table 7. The findings show a unidirectional causality from aid and GDP to recurrent expenditure. However, they demonstrate no Granger causality between capital expenditure, GDP and foreign aid, even though these variables are found to be cointegrated. The latter result is not inconsistent given a low power problem due to the over-fitting of the model as well as a small sample size used in the estimations of this study (see Dolado and Lutkepohl, 1996).

Table 7. Granger causality test

\begin{tabular}{lcc}
\hline Null hypothesis & Wald & p-value \\
\hline$Y$ does not Granger-cause $G_{1}$ & 3.739 & 0.053 \\
$A$ does not Granger-cause $G_{1}$ & 9.609 & 0.002 \\
$G_{1}$ does not Granger-cause $Y$ & 0.268 & 0.605 \\
$A$ does not Granger-cause $Y$ & 0.307 & 0.580 \\
$G_{1}$ does not Granger-cause $A$ & 1.712 & 0.191 \\
$Y$ does not Granger-cause $A$ & 1.530 & 0.216 \\
$Y$ does not Granger-cause $G_{2}$ & 2.493 & 0.114 \\
$A$ does not Granger-cause $G_{2}$ & 0.028 & 0.868 \\
$G_{2}$ does not Granger-cause $Y$ & 0.567 & 0.451 \\
$A$ does not Granger-cause $Y$ & 0.020 & 0.887 \\
$G_{2}$ does not Granger-cause $A$ & 0.092 & 0.762 \\
$Y$ does not Granger-cause $A$ & 0.417 & 0.519 \\
\hline
\end{tabular}




\section{Conclusion}

The paper analyses the fiscal effects of foreign aid in Lesotho over the period 1982-2010. The cointegration test results indicate a strong negative long-run association between recurrent expenditure and foreign aid. The results also show a positive but marginally significant relationship between aid and capital expenditure. Based on these findings, it can be argued that there is no evidence for the presence of aid fungibility since no diversion of aid to recurrent expenditure is observed. In contrast, the Lesotho Highlands Water Project seems to have been effective in terms of changing government budgetary allocations and has had a positive impact on development spending, supporting the notion that provision of loans instead of grants results in the effective use of government funds.

The analysis of this paper has important implications for Lesotho. Firstly, the provision of loans instead of grants can continue to induce some discipline and result in the effective use of funds by the government. Secondly, foreign aid in terms of technical support can be used to broaden the domestic tax base and create more efficiency in tax administration, which could further reduce the country's dependency on foreign aid.

\section{References}

Barro, R. J. (1990). Government spending in a simple model of endogenous growth. Journal of Political Economy, 98, 103-126.

Bhattarai, B. P. (2007). Foreign aid and government's fiscal behaviour in Nepal: An empirical analysis. Economic Analysis and Policy, 37, 41-60.

Boone, P. (1996). Politics and the effectiveness of foreign aid. European Economic Review, 40, 289-329.

Chatterjee, S., Giuliano, P. \& Kaya, I. (2012) .Where has all the money gone? Foreign aid and the composition of government spending. The B.E. Journal of Macroeconomics, 12, Article 26.

Chenery, H. B. \& Strout, A. M. (1966). Foreign assistance and economic development. American Economic Review, 56, 679-733.

Devarajan, S., Rajkumar, A. S. \& Swaroop, V. (2006). Chapter 17 what does aid to Africa finance? Volume Frontiers of Economics and Globalization, 1, 333-355.

Dickey, D. A. \& Fuller, W. A. (1979). Distribution of the estimators for autoregressive time series with a unit root. Journal of the American Statistical Association, 74, 427-431.

Dickey, D. A. \& Fuller, W. A. (1981). Likelihood ratio statistics for autoregressive time series with a unit root. Econometrica, 49, 10571072.

Djankov, S. Montalvo, J. G. \& Reynal-Querol, M. (2006). Does foreign aid help? Cato Journal, 26, 1-28.

Dolado, J. \& Lutkepohl, H. (1996). Making Wald tests work for cointegrated VAR systems. Econometric Reviews, 15, 369-386.

Engle, R. F. \& Granger, C. W. J. (1987). Cointegration and error correction: representation, estimation, and testing. Econometrica, 55, 251-276.

Fagernas, S. \& Roberts, J. (2004). The fiscal effects of aid in Uganda. ESAU Working Paper No. 9, London: Overseas Development Institute.

Fagernas, S. \& Roberts, J. (2004). The fiscal effects of aid in Zambia. ESAU Working Paper No. 10, London: Overseas Development Institute.

Fagernas, S. \& Schurich, C. (2004). The fiscal effects of aid in Malawi. ESAU Working Paper No. 7, London: Overseas Development Institute.

IMF (2012). Kingdom of Lesotho: poverty reduction strategy paper - national strategic development plan. Country Report No. 12/102, Washington: International Monetary Fund.

Johansen, S. (1988). Statistical analysis of cointegration vectors. Journal of Economic Dynamics and Control, 12, $231-254$.

Johansen, S. (1995). Likelihood-based inference in cointegrated vector autoregressive models. Oxford: Oxford University Press.

Masenyetse, R. F. \& Motelle, S. I. (2012). Government revenue-expenditure nexus in Lesotho: the decline in SACU revenue. American Journal of Economics, 2, 8-14.

Matlosa, K. (1999). Aid, development and democracy in Lesotho, 1966-1996. Paper presented to the Workshop on Aid, Development and Democracy in Southern Africa, 21-22 November, Cape Town: University of Western Cape.

Pack, H. \& Pack, J. R. (1990). Is foreign aid fungible? The case of Indonesia. The Economic Journal, 100, 188-194.

Pack, H. \& Pack, J. R. (1993). Foreign aid and the question of fungibility. Review of Economics and Statistics, 75, 258-265.

Swaroop, V., Jhab, S. \& Rajkumara, A. S. (2000). Fiscal effects of foreign aid in a federal system of governance: The case of India. Journal of Public Economics, 77, 307-330.

Thamae. R. I. (2012). The Role of Food Price Inflation in Lesotho. Int. J. Economic Policy in Emerging Economies, 5, 367-386.

Thamae. R. I. (2013). The Growth of Government Spending in Lesotho. Economic Analysis and Policy, 43, 339-352. 